\title{
Factors Associated with Dental Care Utilization among Pregnant Women at Klapanunggal Health Centre, Bogor, Indonesia
}

\author{
Itsna Widita'), Sutanto Priyo Hastono²) \\ ${ }^{1)}$ Masters Program in Quality of Health Services, Faculty of Public Health, \\ Universitas Indonesia \\ 2)Department of Biostatistics, Faculty of Public Health, Universitas Indonesia
}

\begin{abstract}
Background: Oral health care during pregnancy is important for the health of the mother and child.During pregnancy, many changes occur in oral cavity that can be linked to periodontal disease, including gingivitis and periodontitis. Oral health condition of pregnant women may adversely bring impacts such as preterm low birth weight (PLBW) and premature birth. Pregnant women need to regularly check oral health to a dentist. However, the number of utilization of dental service which is indicated by pregnant women's dental visit data in Indonesia is still very low.This study aimed to determine factors associated with dental care visit among pregnant women.

Subjects and Method: This was a cross-sectional study conducted at Klapanunggal health center, Bogor, Indonesia. A sample of 60 pregnant women was selected by consecutive sampling. The dependent variable was dental care utilization. The independent variables were oral health problem and knowledge. The data were collected by questionnaires and analyzed by a multiple logistic regression.
\end{abstract}

Results: Most of pregnant women claimed that their oral health was good (35\%) or average (35\%). On the contrary, most of them admitted of having had at least one oral health problem (55\%), including bleeding gum (35\%), dental cavity (33.3\%), and painfull teeth (10\%). However, only $23.3 \%$ of pregnant women visited dentist during the current pregnancy. Factors associated with dental visit were existence of oral health problem $(\mathrm{OR}=6.41 ; \mathrm{p}=0.019)$ and oral health knowledge during pregnancy $(\mathrm{OR}=4.03 ; \mathrm{p}=0.050)$ after controlling education, employment, income, and health insurance.

Conclussion: utilization of oral health care service among pregnant women was low. Pregnant women who reported dental visit were more likely to be those who had oral health problem and who had good oral health knowledge during pregnancy.

Keywords: oral health, pregnancy, antenatal care, dental visit

\section{Correspondence:}

Itsna Widita, Masters Program in Quality of Health Services, Faculty of Public Health, Universitas Indonesia. Email: itsnawidita@gmail.com

\section{BACKGROUND}

$\overline{\text { Physiological conditions during pregnancy }}$ can cause some changes in oral health. Immunological factors, diet and behavior related to pregnancy are believed to be contributing factors. Pregnant women are very susceptible to gingival and periodontal disease. They may not experience symptoms until the advanced disease stage, thereby unconsciously increasing perinatal risk. Perinatal risks include preterm birth, low birth weight (LBW), preeclampsia, gingival tissue ulceration, granulomas, and dental carries (Sajjan et al., 2015).

Low birth weight (LBW) and premature birth is when the birth weight is less than 2,500 grams and is born before 37 weeks of gestation. In pregnant women with periodontitis, infected periodontal tissue is a reservoir of bacteria and bacterial products can spread to the fetal placenta. Pregnant women with severe periodontitis, 
Journal of Health Promotion and Behavior (2019), 4(2): 145-152

https://doi.org/10.26911/thejhpb.2019.04.02.07

infectious agents and products activate extra-oral inflammation, including in the fetus-placenta, which not only causes preterm birth but also causes preeclampsia and limits the growth of the baby in the uterus (Zi et al., 2015)

Nowadays all pregnant women are recommended to receive a comprehensive oral health evaluation and risk assessment during pregnancy. There is still debate about the benefits of periodontal treatment in preventing adverse pregnancy conditions.However, it is clear that dental care during pregnancy is safe and can significantly improve maternal oral health and prevent the risk of early caries in infants (George et al., 2013)

Recent studies show that around 50\% of pregnant women do not visit the dentist, even when they feel a complaint in the teeth and mouth. The results of another recent study conducted in South India revealed that despite dental pain, the utilization of dental care by pregnant women is still very low (Gambhir et al., 2015) Various factors are said to be a barrier for pregnant women in obtaining dental care during pregnancy. These factors include socio-economic and socio-cultural factors, lack of public awareness about the importance of oral health, and also the concerns about fetal safety during dental care (George et al., 2013)

In many countries special programs have been developed to improve oral health, increase the knowledge of pregnant women about oral health during pregnancy, and oral health for their children. In Indonesia, oral health care for pregnant women is regulated in Minister of Health Regulation No. 89 of 2015 (Minister of Health Regulation RI Number 89 of 2015) which explains that dental and oral health service activities for pregnant women can be carried out at first-level health facilities in the form of counseling, preliminary examina- tions, and referrals as steps to cure oral and dental diseases (Ministry of Health, 2015).

In Bogor, according to community health center report in 2017, there were 1,557 LBW (1.28\%) out of a total of 131,446 babies born. From the report 100\% of LBW cases had been handled by health facilities, but there were 44 infants (2.83\%) of infant deaths due to LBW (Bogor District Health Office, 2018). In 2003, the Indonesian Dental Association (PDGI) stated that gingival inflammation was problems of teeth and mouth that are often experienced by pregnant women where 5-10\% experience swelling of the gums. Another study by Anggraini at Serpong Health Center (2015) also showed that from $32.4 \%$ of pregnant women had never been to a dentist in their lives, $35.5 \%$ had last visited a dentist 1 year ago, and $32.4 \%$ had not seen a dentist for a long time (Anggraini et al., 2015).

Little is known about the oral health condition of pregnant women in Bogor. However, existing study shows that pregnant women have lack information about the implications of poor oral health during pregnancy as well as barriers to accessing dental services during the pregnancy period. Dental and oral health strategies can be implemented for pregnant women.Moreover, it is necessary to further investigate the utilization of dental and oral health services among pregnant women attending antenatal care at the Klapanunggal Health Center.

\section{SUBJECTS AND METHOD}

\section{Study Design}

This was a cross sectional study conducted at the Klapanunggal Health Center, Bogor, on April 2019.

\section{Population and Sampling}

A total 60 pregnant women was selected for this study with the inclusion criteria of this study were pregnant women with a gesta- 
tional age of more than 2 weeks and the pregnancy is positif based on the results of a midwife or doctor's examination.

\section{StudyVariables}

The dependent variable was dental care visit by pregnant women. The independent variables included maternal age, formal education of the mother, maternal employment status, family income, health insurance, dental and oral health problems experienced, and knowledge about oral health.

\section{Data Analysis}

Frequencies and percentages for categorical variables were calculated and tabulated. Multivariable logistic regression model was used to calculate Odds Ratio (OR) and 95\% confidence intervals ( $95 \% \mathrm{CI}$ ) to find factors related to dental visits to pregnant women.

\section{Research Ethics}

The research ethics used in this study was the consent formsigned by the research subjects, anonymous, confidentiality, and research benefits.

\section{RESULTS}

Table 1 shows the sociodemographic characteristics of the respondents. Most pregnant women who were the respondents aged less than 35 years were 51 people (85\%). As many as $51.7 \%$ of respondents had a senior high school education, 26.7\% had an elementary school education, 20\% had a junior high school education, and only $1.7 \%$ had no formal education. Most respondents did not work (91.7\%) and had a family income below the minimum wage (53.3\%) and most had health insurance in the form of Social Insurance Administration Organization (BPJS) (80\%) the rest did not have health insurance (20\%). Most respondents $(43.3 \%)$ were second pregnancies, and $45 \%$ were in the third trimester of pregnancy.

\section{Table 1. Characteristics of Pregnant Women}

\begin{tabular}{|c|c|c|}
\hline Characteristics & $\mathbf{n}$ & $\%$ \\
\hline \multicolumn{3}{|l|}{ Age of pregnant women } \\
\hline$<35$ years & 51 & $85 \%$ \\
\hline$>35$ years & 9 & $15 \%$ \\
\hline \multicolumn{3}{|l|}{ Maternal Age } \\
\hline Uneducated & o & $0 \%$ \\
\hline Junior High School & 12 & $20 \%$ \\
\hline Senior High School & 31 & $51.7 \%$ \\
\hline \multicolumn{3}{|l|}{ Maternal employment status } \\
\hline Unemployed & 55 & $91.7 \%$ \\
\hline Employed & 5 & $8.3 \%$ \\
\hline \multicolumn{3}{|l|}{ Family income } \\
\hline Under the Regional Minimum Wage & 32 & $53.3 \%$ \\
\hline Above the Regional Minimum Wage & 28 & $46.7 \%$ \\
\hline \multicolumn{3}{|l|}{ Health Insurance } \\
\hline Do not have & 12 & $20 \%$ \\
\hline Social Insurance Administration Organization (BPJS) & 28 & $80 \%$ \\
\hline Other & o & $0 \%$ \\
\hline \multicolumn{3}{|l|}{ Pregnancy: } \\
\hline First pregnancy & 19 & $31.7 \%$ \\
\hline Second pregnancy & 26 & $43.3 \%$ \\
\hline Third pregnancy & 14 & $23.3 \%$ \\
\hline$\geq$ fourth pregnancy & 1 & $1.7 \%$ \\
\hline \multicolumn{3}{|l|}{ Gestational age } \\
\hline $1^{\text {st }}$ Trimester & 10 & $16.7 \%$ \\
\hline $2^{\text {nd }}$ Trimester & 23 & $38.3 \%$ \\
\hline $3^{\text {rd }}$ Trimester & 27 & $45 \%$ \\
\hline
\end{tabular}


Journal of Health Promotion and Behavior (2019), 4(2): 145-152

https://doi.org/10.26911/thejhpb.2019.04.02.07

Table 2. Dental and Oral Health according to Respondents' Perception

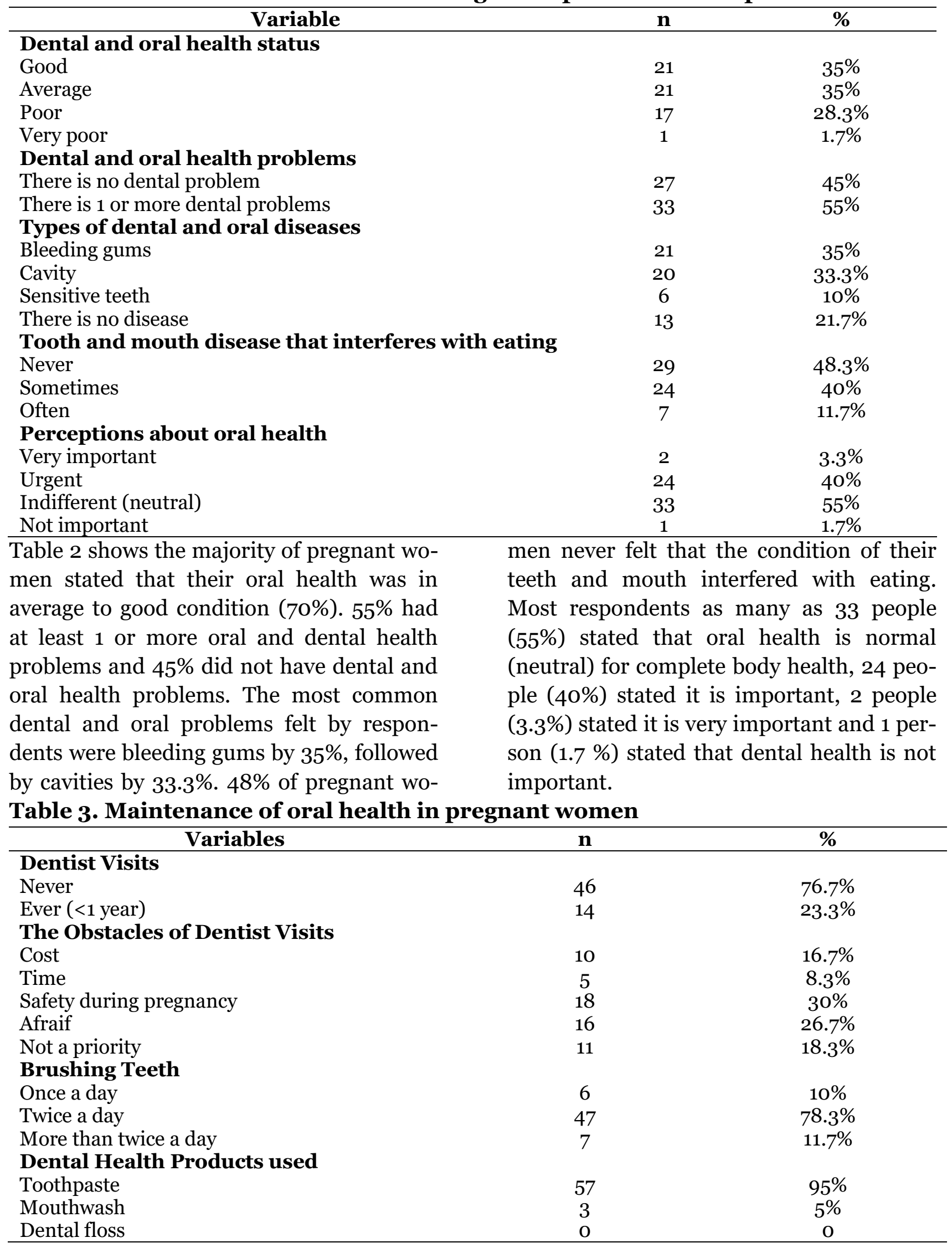


Table 3 shows that there were only 14 respondents $(23.3 \%)$ of pregnant women visited the dentist for less than 1 year. The obstaclesfor pregnant women in visiting dentists: 18 people (30\%) stated that it wasbecause of safety during pregnancy, 16 people (26.75\%) stated that it was because they were afraid, 11 people (18.3\%) stated that it wasbecause it was not a priority, 10 people (16.3\%) stated that it wasbecause of cost constraints, and 5 people (8.3\%) stated that it wasdue to time constraints. Toothbrush frequency was mostly twice a day.The majority of 57 people (95\%) used only toothpaste, and 3 people (5\%) added mouthwash in addition to toothpaste.

Table 4. Knowledge of Dental and Oral Health

\begin{tabular}{lcc}
\hline Knowledge of Dental and OralHealth & n & \% \\
\hline Poor knowledge & 35 & 58.3 \\
Good knowledge & 25 & 41.7 \\
\hline
\end{tabular}

Table 4 shows that 35 (58.3\%) respondents had poor oral health knowledge, and the remaining 25 (41.7\%) respondents had good oral health knowledge.The next stage is each independent variable (maternal age, maternal education, maternal employment

Table 5. Bivariate Analysis Results

\begin{tabular}{lcc}
\hline \multicolumn{1}{c}{ Variables } & OR & p \\
\hline Maternal age & 1.82 & 0.457 \\
Education & 0.01 & 0.257 \\
Employment status & 2.39 & 0.384 \\
Family income & 1.73 & 0.370 \\
Health insurance & 4.09 & 0.135 \\
Oral and dental health problems & 4.00 & 0.037 \\
Dental and oral health knowledge & 2.27 & 0.182 \\
\hline
\end{tabular}

Table 6. Results of Multiple Logistic Regression Analysis

\begin{tabular}{lcccc}
\hline Variables & b & OR & 95\% CI & p \\
\hline Health insurance & 1.55 & 4.70 & 0.48 to 45.74 & 0.183 \\
Oral and dental health problems & 1.86 & 6.41 & 1.35 to 30.37 & 0.019 \\
$\begin{array}{l}\text { Dental and oral health knowledge N } \\
\text { observation=0.187 }\end{array}$ & 1.39 & 4.03 & 0.99 to 16.25 & 0.050 \\
Nagelkarke $\mathrm{R}^{2}=0.283$ & & & & \\
\hline
\end{tabular}

From the results of multivariate analysis, the variables that were significantly associatedwith dental visits of pregnant women were the variable of oral and dental health problems and oral health knowledge. While the health insurance variable was as a controlling variable. The results of the analysis showed that the presence or absence of the status, family income, ownership of health insurance, dental and oral health problems and knowledge) is associated with the dependent variable of dentist visits for at least onepast year. The bivariate selection results are as follows. most dominant dental and oral health problems was associatedwith the dentist visits of pregnant women. The odds ratio (OR) of the variable oral and dental health problems was 6.4. It means that mothers who have 1 or more oral and dental health problems are 6 times more likely to visit the dentist than mothers who do not have den- 
Journal of Health Promotion and Behavior (2019), 4(2): 145-152

https://doi.org/10.26911/thejhpb.2019.04.02.07

tal and oral problems, after being controlled by the guarantee variable health and knowledge of dental and oral health.

\section{DISCUSSION}

The results showed that more than half of respondents $(55 \%)$ had oral and dental health problems which were bleeding gums (35\%), cavities (33.3\%of respondents) and sensitive teeth (10\% of respondents). One of the causes of poor dental and mouth conditions during pregnancy is due to hormonal and dietary changes (George et al., 2013).

The overall actions of maintaining oral health of the respondents were good. 78.3\% respondents brushed their teeth twice a day, $95 \%$ used only toothpaste, and $3 \%$ added mouthwash in maintaining oral health during pregnancy. This is consistent with the study of Bamanikar et al. (2013) which stated that $100 \%$ of respondents routinely brush their teeth (Bamanikar and Kee, 2013). However, the time when they were brushing their teeth was not asked further in this study. Basic Health Research (2013) encouraged people to practice brushing their teeth every day, but people who brush their teeth at the right time after breakfast and before going to bed at night are only $3.8 \%$ and $27.3 \%$ (Ministry of Health, 2013).

Most of the respondents $76.7 \%$ had never done a dental examination during pregnancy. This is in line with a study in Sydney that reported that more than half of respondents experienced oral and dental health problems, but only less than a third visited dentists (George et al., 2013). Obstacles to visiting dentists in this study were because of safety during pregnancy (30\%), afraid $(26.7 \%)$, oral health was not a priority (18.3\%), cost constraints (16.7\%), and time constraints (16.7\%). Based on the results of this study, dentists are expected to deliver Dental Health Education (DHE) to pregnant mother patients. Dentists are expected to convey that untreated dental and oral health can have an impact on the fetus (LBW and premature babies) and dental care is safe to be done during pregnancy (Ministry of Health, 2012).

Fear is the second biggest obstacle for pregnant women in visiting dentists. In epidemiological studies in United States, the prevalence of dental fear is $13.1-19.8 \%$, but gender differences are not reported. Things that cause fear, among others: due to bad experiences that cause trauma, experiences or stories of others, dentists who are not empathic, fear of tools (needles and burs), fear of machine noises, and sensitive personal traits (Armfield, 2009).

The next inhibiting factor, amounting to $18.3 \%$ of respondents considered oral health was not a priority. This feeling is called the perceived need originating from the patient's side on the basis of beliefs about a disease that is subjective (Armfield, 2009). Based on the results of Basic Health Research (2013), only $25.9 \%$ of the population felt that dental and mouth health was problematic, but those who did dental examinations did not reach 50\% (Ministry of Health, 2013).

Previous studies conducted by Bianca (2009) stated the the results of logistic regression tests. Factors that significantly associatedwith the behavior of dentists visits include personal factors (marital status, dentist visits before pregnancy, and the use of inter-proximal cleaning tools) (Mwaiswelo, 2007). This is in line with this study, where the results of the bivariate analysis showed that factors that were significantly associated with dentist visit included health insurance, dental and oral problems and knowledge. $80 \%$ of respondents have health insurance in the form of Social Insurance Administration Organization (BPJS) 
that can cover the oral health of the participants (Thabrany, 2014).

However, from the multivariable logistic regression test the existence of dental and oral health problems had a significant association with dentist visit of pregnant women $(\mathrm{OR}=6.4 ; \mathrm{p}=0.019)$. Pregnant women with dental and mouth health problems 6 times have the opportunity to see a dentist compared to pregnant women who have no dental and oral health problems. This is in line with the study conducted by Chung et al. (2014). It was in California that pregnant women who visited dentist more than 6 months ago, had poorer dental and oral health status (marked by higher BOP, PI and DMF-T (Chung et al., 2014)

Another factor that was significantly associatedwith dental visits was knowledge of oral health during pregnancy $(\mathrm{OR}=4.02$; $\mathrm{p}=0.05$ ). Pregnant women who have good oral health knowledge are four times more likely to see a dentist than those who lack knowledge. This is consistent with a study in East China in 2014 which showed a low percentage of dental and oral care utilization in pregnant women who had low oral health knowledge related to pregnancy (Sun et al., 2014)

The results of this study can be concluded that the utilization of dental and oral health services among pregnant women is still low. Pregnant women make dental visits because those who have oral health problems and who have good oral health knowledge during pregnancy with obstacles that include the safety of obtaining dental and oral care during pregnancy, fear, and consider oral health is not a priority.

\section{AUTHOR CONTRIBUTION}

Itsna Widita collected the data, examined the data, and wrote the manuscript.
FUNDING AND SPONSORSHIP

There was no external fund.

\section{CONFLICT OF INTEREST}

There is no conflict of interest in this study.

\section{ACKNOWLEDGMENT}

The authors would like to express gratitude to mothers who were participated in this study and also Klapanunggal Health Office who gave permission for this study.

\section{REFERENCE}

Anggraini, Rani,and Andreas P (2015). Hamil (Studi Pendahuluan di Wilayah Puskesmas Serpong, Tangerang Selatan). Maj.Ked.Gi Ind, 1(2): 193-200.

Armfield JM (2009). Dental fear and adult oral health in Australia. (May), 2009.

Bamanikar S, Kee LK (2013). Knowledge, Attitude and Practice of Oral and Dental Healthcare in Pregnant Women. 28(4): 288-291.

Chung LH, Gregorich SE, Armitage GC, Gonzalez-Vargas JAS (2014) Sociodemographic Disparities and Behavioral Factors in Clinical Oral Health Status During Pregnancy. Community Dent Oral Epidemiol., 42(2): 151-159.

Health Office Bogor Regency. (2018). Profil Kesehatan Kabupaten Bogor Tahun 2017. Bpgor.

Gambhir R, Nirola A, Gupta T, Sekhon T, \& Anand S (2015). Oral health knowledge and awareness among pregnant women in India: A systematic review. Journal of Indian Society of Periodontology, 19(6): 612. Retrived from https://doi.org/10.4103/0972124X.162196

George A, Johnson M, Blinkhorn A, Ajwani S, Bhole S, Yeo AE, Ellis S (2013). The oral health status, practices and knowledge of pregnant women in 
south-western Sydney. Australian Dental Journal, 58(1): 26-33. Retrived fromhttps://doi.org/10.1111/adj. 12024

Ministry of Health (2012). Pedoman Pemeliharaan Kesehatan Gigi dan Mulut Ibu Hamil dan Anak Usia Balita bagi Tenaga Kesehatan di Fasilitas Pelayanan Kesehatan. Jakarta: Kemenkes RI.

Ministry of Health (2013). Riset Kesehatan Dasar 2013.

Ministry of Health (2015). Peraturan Menteri Kesehatan No 89 Tahun 2015.

Mwaiswelo RO MJ (2007). Oral health Pregnant, knowledge and behavior among women in Keyla District, Mabeya. Tanzania. Tanzania Dent J., 14(2): 47.

Sajjan P, Pattanshetti JI, Padmini C, Nagathan VM, Sajjanar M, Siddiqui T,
Sajjan $P$ (2015). practice and pregnant woman, Nil Oral Health Related Awareness and Practices among Pregnant Women in Bagalkot District, Karnata$\mathrm{ka}$, India. Journal of International Oral Health, 7(2): 1-5.

Sun W, Guo J, Li X, Zhao Y, Chen H, W. G. (2014). The Routine Utilization of Dental Care during Pregnancy in Eastern China and The Key Underlying Factors: a Hangzhou City study. Plos One, 9(6): e98780.

Thabrany H. (2014). Jaminan Kesehatan Nasional. Jakarta: PT Raja Grafindo Persada.

Zi MYH, Longo PL, Bueno-Silva B, Mayer MPA (2015). Mechanisms Involved in the association between periodontitis and complications in pregnancy. Frontiers in Public Health, 2(1): 1-13. Retrived from https://doi.org/10.3389/fpubh.2014.00290 